\title{
Synthesis of Biologically Important Chiral Morpholine Derivatives
}

\author{
Mohammad Nurnabi and Mohammad Ismail \\ Department of Applied Chemistry and Chemical Technology, \\ University of Dhaka, Dhaka-1000, Bangladesh
}

\begin{abstract}
Electrophile $\left(\mathrm{Br}_{2}\right)$ induced cyclization of optically pure $N$-allyl- $\beta$-aminoalcohols $\mathbf{1 a}$, 1b, 1c and 2a, 2b gave chiral morpholines $(2 R, 5 S)-\mathbf{3 a}$, 3b, 3c and $(2 S, 5 R)-\mathbf{4 a}, \mathbf{4} \mathbf{b}$ respectively. Quenching of the reaction with $\mathrm{Na}_{2} \mathrm{CO}_{3}$ after 5 min afforded $60 \%$ conversion with $100 \%$ de, whilst a 2:1 mixture of two diastereomers was obtained upon complete conversion. However, electron donating substituent $(\mathrm{OMe})$ on the para position of the $C-2$ aryl moiety (substrates $\mathbf{1 b}$ and $\mathbf{2 b}$ ) accelerates the reaction to give $80 \%$ conversion and $50 \%$ isolated yield of single diastereomer after $5 \mathrm{~min}$ and 8:1 mixture of diastereomers on complete conversion after $10 \mathrm{~min}$.
\end{abstract}

\section{Introduction}

$\gamma$-Aminobutyric acid (GABA) is the main inhibitory neurotransmitter in the mamalian nervous system (Wood et al., 2000), which is activated by a class of receptor, known as GABA receptor. The subclass $\mathrm{GABA}_{B}$ receptor is already identified (Bowery et al., 1980; Hill and Bowery, 1981; Bowery and Hill, 1983) and the activation of this receptor causes prolonged synaptic inhibition through restriction of pre-synaptic calcium channel activity and activation of post synaptic potassium channels (Couve et al., 2000; Bettler et al., 1998; Kerr and Ong, 1995; Bowery et al., 2000). The unbalanced presynaptic and post-synaptic neurotransmission triggers a lot of physiological processes and diseases including nociception, cognition, epilepsy, depression and drug addiction (Couve et al., 2000; Bettler et al., 1998) where $\mathrm{GABA}_{\mathrm{B}}$ plays the major roles. Thus activation (by agonists) of $\mathrm{GABA}_{\mathrm{B}}$ causes depression and absence seizure symptom, while blockade (by anta- gonists) causes excessive locomotor activities. It was documented that the blockade of $\mathrm{GABA}_{\mathrm{B}}$ stimulates the locomotor activities and ethanol withdrawal syndrome in mice (Colombo et al., 2001; Carai et al., 2002). $\mathrm{GABA}_{\mathrm{B}}$ Antagonists are thus used in the treatment of absence seizures (Snead, 1992), memory deficits (Mondadori et al., 1992) and countering the respiratory depression caused by excessive doses of $\mathrm{GABA}_{\mathrm{B}}$ agonists (Blythin et al., 1996). It was previously found that chiral morpholine SCH5091 and its non-chiral derivatives are effective antagonists for $\mathrm{GABA}_{\mathrm{B}}$ receptor (Colombo et al., 2001; Carai et al., 2002; Blythin et al., 1996; Ong et al., 1999). Many more researches should have been devoted to the synthesis of morpholine derivatives having $\mathrm{GABA}_{B}$ antagonizing properties as only a few methods are so far disclosed (Kelley et al., 1996; Largeron et al., 2002). Herein, we like 
to report the synthetic methodology for highly substituted chiral morpholines from optically pure $N$-allyl- $\beta$-amino alcohols using bromine. $N$-allyl- $\beta$-amino alcohol contains a $\delta$-hydroxy alkene moiety and the cyclization of $\gamma$-, $\delta$ - and $\omega$-alkenyl alcohols can be achieved by acid catalysis (Miura et al., 2000), ring closure metathesis (Nicolaou et al., 1980) and halocyclisation (Corey, 1987; Jung and Lew, 1991; Jung et al., 1993). Cyclizations of $\gamma$-hydroxy alkenes by iodine (Saksena et al., 1996; Baldwin and Mclver, 1987; Reitz et al., 1987; Bennet et al., 1992) and cyclization of $\gamma$ - and $\delta$ hydroxy alkenes using phenylselenenyl bromide (Ezquerra et al., 1990) have also been reported.

\section{Materials and Methods}

General technical data: Commercially available reagents were used without further purification. Flash column chromatography was performed on Merck silica gel 60 (230400 mesh). Melting points were determined on a Kofler hot stage apparatus and are uncorrected. Microanalyses were obtained using a Carlo-Erba Model 1106 instrument. Proton nuclear magnetic resonance $\left({ }^{1} \mathrm{H}\right.$ NMR) spectra and nuclear Overhauser effect (n.O.e) experiments were conducted at 300 MHz. on a Bruker DPX300 instrument and at $500 \mathrm{MHz}$. on a Bruker DRX500 spectometer as specified. Chemical shifts are reported in parts per million $(\delta)$ downfield from tetramethylsilane as internal standard reference and coupling constants are given in Hertz (Hz). ${ }^{13} \mathrm{C}$ NMR spectra were recorded with a Bruker DPX300 (75 MHz) and chemical shift values are reported in parts per million (ppm) relative to $\mathrm{CDCl}_{3}$ $(\delta=77.0)$. Mass spectra were obtained on a VG Autospec mass spectrometer at $70 \mathrm{eV}$ using electron impact (EI) or electron spray (ES) ionisation techniques. Infrared spectra were recorded on a Perkin Elmer FT-IR spectrometer either by a film technique on sodium chloride discs by spreading dichloromethane (DCM) solution on the discs. The samples for the film technique were prepared by dissolving a small amount of compounds in dichloromethane and the solutions were poured on to sodium chloride disc and the dichloromethane was allowed to evaporate. Specific rotations were measured at ambient temperature with an Optical Activity Ltd., AA-1000 polarimeter. The $[\alpha]_{D}$ is given in $\operatorname{deg}$ per $\mathrm{dm}$ at $20^{\mathrm{O}} \mathrm{C}$, and the concentration $(c)$ is expressed in $\mathrm{g} 100 \mathrm{~mL}^{-1}$. X-Ray crystallographic structures were determined on a Stoe STADI 4-circle machine.

\section{General procedure for the cyclisation of $\delta$ - alkenols using $\mathrm{Br}_{2}$}

All reactions were performed under nitrogen atmosphere. $N$-Allyl- $\beta$-amino alcohols 1a, $\mathbf{1 b}, \mathbf{1 c}$ or $\mathbf{2 a}, \mathbf{2 b}(0.5 \mathrm{mmol})$ were dissolved in freshly distilled dichloromethane $(2-3 \mathrm{ml})$ in a round bottom flask. The flask was closed with a septum and the solution was 
cooled to $-78^{\mathrm{O}} \mathrm{C}$ by immersing the flask in a mixture of acetone-dry ice. A $10 \%(\mathrm{w} / \mathrm{v})$ solution of bromine in dichloromethane $(0.8$ $\mathrm{ml}, 1.0$ mol eq.) was added dropwise over 5 min. After the addition was complete, the mixture removed from the cooling bath (acetone-dry ice) and immediately quenched with saturated aq. $\mathrm{Na}_{2} \mathrm{CO}_{3}$ solution $(5 \mathrm{ml})$. The dichloromethane layer was separated, the aq. layer was further extracted with dichloromethane $(2 \times 5 \mathrm{ml})$ and the combined organic layer was dried $\left(\mathrm{MgSO}_{4}\right)$, filtered and the filtrate was evaporated under reduced pressure. The residue was purified by flash chromatography on silica gel eluting with petroleum ether-diethylether solvent system.

(2R,5S)-2-(Bromomethyl)-5-isopropyl-2phenylmorpholine (3a):

As a colourless oil $(0.05 \mathrm{~g}, 31 \%) ;[\alpha]_{\mathrm{D}}+4(c$ 1.00 in $\mathrm{CHCl}_{3}$ ) (HRMS: $300.0974\left(\mathrm{M}^{+}+\mathrm{H}\right)$ $\left({ }^{81} \mathrm{Br}\right) ; \quad \mathrm{C}_{14} \mathrm{H}_{20} \mathrm{NOBr}$ requires 300.0963 $\left(\mathrm{M}^{+}+\mathrm{H}\right)\left({ }^{81} \mathrm{Br}\right) ; \delta_{\mathrm{H}}\left(300 \mathrm{MHz}, \mathrm{CDCl}_{3}\right) 0.98$ $(3 \mathrm{H}, \mathrm{d}, J 6.8, \mathrm{Me}), 1.0(3 \mathrm{H}, \mathrm{d}, J 6.8, \mathrm{Me})$, 1.55-1.7 (1H, m, C$\left.\{\mathrm{Me}\}_{2}\right), 2.75-2.85(1 \mathrm{H}$, $\left.\mathrm{m}, 5-\mathrm{H}^{\mathrm{ax}}\right), 3.25\left(1 \mathrm{H}, \mathrm{t}, J 10.7,6-\mathrm{H},{ }^{\mathrm{ax}}\right.$ apparent triplet instead of a double doublet), $3.47(1 \mathrm{H}$, d, $\left.J 11.5, \mathrm{CH}_{2} \mathrm{Br}\right), 3.77(1 \mathrm{H}, \mathrm{d}, J 11.5$, $\left.\mathrm{CH}_{2} \mathrm{Br}\right), 3.95\left(1 \mathrm{H}, \mathrm{dd}, J 10.7\right.$ and $\left.3.3,6-\mathrm{H}^{\mathrm{eq}}\right)$, $3.96\left(1 \mathrm{H}, \mathrm{d}, J 10.8,3-\mathrm{H}^{\mathrm{eq}}\right), 4.52(1 \mathrm{H}, \mathrm{d}, J$ 10.8, 3- $\left.\mathrm{H}^{\mathrm{ax}}\right), 7.25-7.4(3 \mathrm{H}, \mathrm{m}, \mathrm{ArH}), 7.53$ $(2 \mathrm{H}, \mathrm{d}, J 8.2, \mathrm{ArH}) ; \delta_{\mathrm{C}}\left(75 \mathrm{MHz}, \mathrm{CDCl}_{3}\right)$ $18.9(\mathrm{Me}), 19.3(\mathrm{Me}), 31.0(\mathrm{CH}), 39.5$ $\left(\mathrm{CH}_{2}\right), 54.4(\mathrm{CH}), 58.3,71.3\left(\mathrm{CH}_{2}\right), 74.3$ $\left(\mathrm{CH}_{2}\right), 77.9,126.2,128.0,128.8$ and 142.3; $\mathrm{m} / \mathrm{z}$ (ES) 300 and $298\left(100 \%, \mathrm{M}^{+}+\mathrm{H}\right)$; $v_{\max } / \mathrm{cm}^{-1}($ film) 2918, 2714, 2433, 1741,
1654, 1550, 1449, 1353, 1276, 1179, 1111, $1051,941,906,849,762,749,698,563$ and 524.

(2R,5S) -2-(Bromomethyl)- 5 -isopropyl2(4-methoxyphenyl) morpholine (3b) :

As a colourless oil $(0.09 \mathrm{~g}, 52 \%) ;[\alpha]_{\mathrm{D}}+8(c$ 1.00 in $\mathrm{CHCl}_{3}$ ) (Found: C, 54.65; H, 6.70; N, $4.15 ; \mathrm{Br}, 24.1 ; \mathrm{C}_{15} \mathrm{H}_{22} \mathrm{NO}_{2} \mathrm{Br}$ requires $\mathrm{C}$, $54.9 ; \mathrm{H}, 6.75 ; \mathrm{N}, 4.25 ; \mathrm{Br}, 24.30 \%) ; \delta_{\mathrm{H}}(300$ $\left.\mathrm{MHz}, \mathrm{CDCl}_{3}\right) 0.95$ (3H, d, J 6.8, Me), 0.99 $(3 \mathrm{H}, \mathrm{d}, J 6.8, \mathrm{Me}), 1.7-1.75(1 \mathrm{H}, \mathrm{m}$, $\left.\mathrm{C} \underline{\mathrm{H}}\{\mathrm{Me}\}_{2}\right), 2.45-2.5\left(1 \mathrm{H}, \mathrm{m}, 5-\mathrm{H}^{\mathrm{ax}}\right), 3.05$ $\left(1 \mathrm{H}, \mathrm{d}, J 11.5, \mathrm{CH}_{2} \mathrm{Br}\right), 3.4(1 \mathrm{H}, \mathrm{d}, J 11.5$, $\left.\mathrm{CH}_{2} \mathrm{Br}\right), 3.65\left(1 \mathrm{H}, \mathrm{dd}, J 11.7\right.$ and $\left.9.6,6-\mathrm{H}^{\mathrm{ax}}\right)$, $3.75\left(1 \mathrm{H}, \mathrm{d}, J 11.1,3-\mathrm{H}^{\mathrm{eq}}\right), 3.8(3 \mathrm{H}, \mathrm{s}, \mathrm{OMe})$, $3.9\left(1 \mathrm{H}, \mathrm{dd}, J 11.7\right.$ and $\left.3.5,6-\mathrm{H}^{\mathrm{eq}}\right), 4.28(1 \mathrm{H}$, $\left.\mathrm{d}, J 11.1,3-\mathrm{H}^{\mathrm{ax}}\right), 6.9(2 \mathrm{H}, \mathrm{d}, J 9.0, \mathrm{ArH})$, $7.34(2 \mathrm{H}, \mathrm{d}, J$ 9.0, $\mathrm{ArH}) ; \delta_{\mathrm{C}}(75 \mathrm{MHz}$, $\left.\mathrm{CDCl}_{3}\right) 19.3(\mathrm{Me}), 19.4(\mathrm{Me}), 29.9(\mathrm{CH})$, $37.6\left(\mathrm{CH}_{2}\right), 52.9(\mathrm{CH}), 55.6(\mathrm{OMe}), 60.4$, $65.0\left(\mathrm{CH}_{2}\right), 74.6\left(\mathrm{CH}_{2}\right), 114.0,128.0,128.8$ and $142.3 ; \mathrm{m} / \mathrm{z}$ (ES) 330 and $328(100 \%$, $\left.\mathrm{M}^{+}+\mathrm{H}\right), v_{\max } / \mathrm{cm}^{-1}($ film) 3318, 2958, 2899, 2829, 2800, 1614, 1583, 1515, 1464, 1448, $1275,1261,1180,1081,1032,831,809$, $764,750,612$ and 547.

Methyl - 4 - [(2R,5S) -2 - (bromomethyl) 5 - isopropyl - 2 - phenylmorpholin - 2 yl]benzoate (3c):

As a colourless oil $(0.07 \mathrm{~g}, 32 \%) ;[\alpha]_{\mathrm{D}}+10$ (c 1.00 in $\mathrm{CHCl}_{3}$ ). A small portion of the oily product was converted to the hydrobromide salt by treating with ethereal $\mathrm{HBr}$ in ether. The product precipitated as a colourless solid which crystallized from EtOH as colourless plates, m. p. $154-156^{\mathrm{O}} \mathrm{C}$ 
(HRMS : $438.0115 \quad\left(\mathrm{M}^{+}\right) \quad\left({ }^{79,81} \mathrm{Br}\right)$; $\mathrm{C}_{16} \mathrm{H}_{22} \mathrm{NO}_{3} \mathrm{Br}(\mathrm{HBr})$ requires $438.0102\left(\mathrm{M}^{+}\right)$ $\left({ }^{79,81} \mathrm{Br}\right) ; \delta_{\mathrm{H}}\left(300 \mathrm{MHz}, \mathrm{CDCl}_{3}\right) 0.98(3 \mathrm{H}, \mathrm{d}$, $J$ 6.8, Me), $1.03(3 \mathrm{H}, \mathrm{d}, J 6.8, \mathrm{Me}), 1.6-1.7$ $\left(1 \mathrm{H}, \mathrm{m}, \mathrm{C} \underline{\mathrm{H}}\{\mathrm{Me}\}_{2}\right), 2.75-2.85(1 \mathrm{H}, \mathrm{m}, 5-$ $\left.\mathrm{H}^{\mathrm{ax}}\right), 3.25\left(1 \mathrm{H}, \mathrm{t}, J 10.8,6-\mathrm{H}^{\mathrm{ax}}{ }^{\text {a }}\right.$ apparent triplet instead of a double doublet), $3.45(1 \mathrm{H}$, $\left.\mathrm{d}, J 11.5, \mathrm{CH}_{2} \mathrm{Br}\right), 3.88(1 \mathrm{H}, \mathrm{d}, J 11.5$, $\left.\mathrm{CH}_{2} \mathrm{Br}\right), 3.9\left(3 \mathrm{H}, \mathrm{s}, \mathrm{CO}_{2} \mathrm{Me}\right), 3.94(1 \mathrm{H}, \mathrm{dd}, J$ 10.8 and $\left.7.3,6-\mathrm{H}^{\mathrm{eq}}\right), 3.95(1 \mathrm{H}, \mathrm{d}, J 11.0,3-$ $\left.\mathrm{H}^{\mathrm{eq}}\right), 4.52\left(1 \mathrm{H}, \mathrm{d}, J 11.0,3-\mathrm{H}^{\mathrm{ax}}\right), 7.62(2 \mathrm{H}, \mathrm{d}$, $J$ 8.7, ArH), $8.0(2 \mathrm{H}, \mathrm{d}, J 8.7, \mathrm{ArH}) ; \delta_{\mathrm{C}}(75$ $\left.\mathrm{MHz}, \mathrm{CDCl}_{3}\right) 18.9(\mathrm{Me}), 19.2(\mathrm{Me}), 31.0$ $(\mathrm{CH}), 39.0\left(\mathrm{CH}_{2}\right), 52.5(\mathrm{CH}), 54.4(\mathrm{OMe}$ ester), 58.7, $71.3\left(\mathrm{CH}_{2}\right), 74.0\left(\mathrm{CH}_{2}\right), 126.3$, 129.8, 130.1, 147.5 and 167.2 (CO ester); $\mathrm{m} / \mathrm{z}$ (ES) 438 and $436\left(\mathrm{M}^{+}+\mathrm{H}\right) ; v_{\max } / \mathrm{cm}^{-}$ ${ }^{1}$ (film) 3326, 3029, 2961, 2914, 2861, 1703, 1667, 1493, 1452, 1265, 1245, 1082, 1064, $1031,851,757,736$ and 700 .

\section{(2S,5R)-2-(Bromomethyl)-2,5-diphenyl morpholine (4a):}

As a cplourless oil $(0.05 \mathrm{~g}, 30 \%) ;[\alpha]_{\mathrm{D}}-34(c$ 1.00 in $\mathrm{CHCl}_{3}$ ) (HRMS: $334.0605\left(\mathrm{M}^{+}+\mathrm{H}\right)$ $\left({ }^{81} \mathrm{Br}\right) ; \quad \mathrm{C}_{17} \mathrm{H}_{18} \mathrm{NOBr}$ requires 334.0630 $\left(\mathrm{M}^{+}+\mathrm{H}\right) \quad\left({ }^{81} \mathrm{Br}\right) ; \quad \delta_{\mathrm{H}} \quad\left(300 \mathrm{MHz}, \mathrm{CDCl}_{3^{-}}\right.$ $\left.\mathrm{CF}_{3} \mathrm{COOD}\right) 3.79$ (1H, d, $J$ 13.8, $\mathrm{CH}_{2} \mathrm{Br}$ ), $3.88\left(1 \mathrm{H}, \mathrm{d}, J 13.8, \mathrm{CH}_{2} \mathrm{Br}\right), 4.00(1 \mathrm{H}, \mathrm{dd}, J$ 12.8 and $4.1,6-\mathrm{H}), 4.16(1 \mathrm{H}, \mathrm{d}, J 11.8,3-\mathrm{H})$, $4.25(1 \mathrm{H}, \mathrm{dd}, J 12.8$ and 4.6, 6-H), $4.38(1 \mathrm{H}$, $\mathrm{d}, J 11.8,3-\mathrm{H}), 4.60-4.65(1 \mathrm{H}, \mathrm{m}, 5-\mathrm{H})$, 7.30-7.60 (10H, m, ArH); $\delta_{\mathrm{C}}(75 \mathrm{MHz}$, $\left.\mathrm{CDCl}_{3}\right) 40.1\left(\mathrm{CH}_{2}\right), 54.0\left(\mathrm{CH}_{2}\right), 62.1\left(\mathrm{CH}_{2}\right)$, 65.8, $67.3(\mathrm{CH}), 113.7,117.5,127.5,129.7$, 129.9, 130.4, 130.6, 131.4, 136.2 and 136.7; $\mathrm{m} / \mathrm{z}$ (ES) 334 and $332\left(\mathrm{M}^{+}+\mathrm{H}\right) ; v_{\max } / \mathrm{cm}^{-}$ ${ }^{1}$ (film) 2961, 2879, 2741, 2456, 1612, 1577,
$1555,1514,1437,1273,1258,1179,1086$, 1031, 909, 826, 790, 763, 697 and 559.

\section{(2S,5R)-2-(Bromomethyl)-2-(4-methoxy- phenyl)-5-phenylmorpholine (4b) :}

As a colourless oil $(0.11 \mathrm{~g}, 50 \%) ;[\alpha]_{\mathrm{D}}-26(c$ 1.00 in $\mathrm{CHCl}_{3}$ ). A small portion of the oily product was converted to the hydrobromide salt by treating with ethereal $\mathrm{HBr}$ in ether. The product precipitated as colourless solid which crystallized from EtOH as colourless plates, m. p. 141-143 ${ }^{\circ} \mathrm{C}$ (Found: C, 48.6; H, $4.75 ; \mathrm{N}, 2.95 ; \mathrm{Br}, 35.85 ; \mathrm{C}_{18} \mathrm{H}_{20} \mathrm{NO}_{2} \mathrm{Br}(\mathrm{HBr})$ requires $\mathrm{C}, 48.8 ; \mathrm{H}, 4.75 ; \mathrm{N}, 3.15 ; \mathrm{Br}, 36.05$ $\%) ; \delta_{\mathrm{H}}\left(500 \mathrm{MHz}, \mathrm{CDCl}_{3}-\mathrm{CF}_{3} \mathrm{COOD}\right) 3.55$ $\left(1 \mathrm{H}, \mathrm{d}, J 11.7, \mathrm{CH}_{2} \mathrm{Br}\right), 3.7(1 \mathrm{H}, \mathrm{d}, J 11.7$, $\left.\mathrm{CH}_{2} \mathrm{Br}\right), 3.8(1 \mathrm{H}, \mathrm{d}, J 11.2,3-\mathrm{H}), 3.83(1 \mathrm{H}$, d, $J 11.2,3-\mathrm{H}), 3.84(3 \mathrm{H}, \mathrm{s}, \mathrm{OMe}), 4.33(1 \mathrm{H}$, dd, $J 13.6$ and $3.9,6-\mathrm{H}), 4.4(1 \mathrm{H}$, dd, $J 13.6$ and $2.76-\mathrm{H}), 4.45-4.47(1 \mathrm{H}, \mathrm{m}, 5-\mathrm{H}), 7.0$ $(2 \mathrm{H}, \mathrm{d}, J 8.8, \mathrm{ArH}), 7.37$ (2H, d, $J 8.8, \mathrm{ArH})$, 7.48-7.5 (3H, m, ArH), 7.75-7.76 (2H, m, $\mathrm{ArH}) ; \delta_{\mathrm{C}}\left(75 \mathrm{MHz}, \mathrm{CDCl}_{3}\right) 46.4\left(\mathrm{CH}_{2}\right), 53.9$ $\left(\mathrm{CH}_{2}\right), 55.6(\mathrm{CH}), 60.4(\mathrm{OMe}), 68.3,74.8$, $113.9,126.7,127.7,128.1,128.4,129.0$, $134.8,140.5$ and $159.3 ; \mathrm{m} / \mathrm{z}$ (ES) 444 and $442\left(\mathrm{M}^{+}+\mathrm{H}\right) ; \quad v_{\max } / \mathrm{cm}^{-1}($ film) $3308(\mathrm{NH})$, 3066, 2967, 2912, 2802, 1719 (CO ester), $1609,1578,1548,1474,1436,1410,1326$, $1275,1223,1206,1118,1040,1017,967$, $940,854,822,773,700$ and 590.

\section{Results and Discussion}

The optically pure $N$-allyl- $\beta$-amino alcohols were synthesized by employing a palladium catalyzed three component cascade reactions (Gai et al., 2001) and were subjected to various electrophile mediated cyclization 
<smiles>C=C([Al])CN[C@@H](CO)C(C)C</smiles>

(S)-1
b, $\mathrm{Ar}=p-\mathrm{MeOC}_{6} \mathrm{H}_{4}-$
c, $p-\mathrm{MeO}_{2} \mathrm{CC}_{6} \mathrm{H}_{4}$<smiles>C=C([Hg])CNC(CO)C(C)C</smiles>

(S)-1

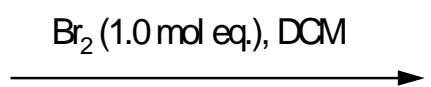

$-78^{\circ} \mathrm{C}, \mathrm{N}_{2}, 5 \mathrm{~min}, \mathrm{Na}_{2} \mathrm{CO}_{3}$<smiles>C=C([Al])CNC(CO)c1ccccc1</smiles>

(R)-2 a, $A r=P h$

b, $\mathrm{Ar}=p-\mathrm{MeOC}_{6} \mathrm{H}_{4}^{-}$
$\mathrm{Br}$

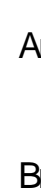<smiles>CCC12CC(CO)(CO1)CC2C(C)C</smiles>

$(2 R, 5 S)-3$<smiles>CC(C)C1COC([Al])(CBr)C1</smiles>

(2S, 5S)-3

\section{Scheme 1}

conditions (Table I). A brief investigation revealed that the best result is achievable by using $\mathrm{Br}_{2}$ solution in dichloromethane (1.0 mol eq.) at $-78^{\mathrm{O}} \mathrm{C}$ for $5 \mathrm{~min}$. The cyclization of the $\delta$-hydroxy alkene moiety could give rise to two diastereomers (Scheme 1). However, the diastereoselectivity is dependent to the reaction conditions (Table I). Substrates were dissolved in dry dichloromethane (DCM), cooled to $-78^{\mathrm{O}} \mathrm{C}$ and $10 \% \mathrm{Br}_{2}$ solution (1.0 mol eq.) was added drop wise under nitrogen, the mixture was left for $5 \mathrm{~min}$ at the same temperature and then quenched with saturated aq. solution of $\mathrm{Na}_{2} \mathrm{CO}_{3}$. Monitoring the reaction by NMR showed that after $5 \mathrm{~min}$ the reaction had proceeded to $60 \%$ to afford a single diastereomer in 30-32\% isolated yield (Table I, entry 5). Substrate 1b undergoes $80 \%$ conversion over a 5 min reaction time with the production of a single diastereomer of the respective product in $50 \%$ yield
(Table I, entry 9). However, after a reaction time of $10 \mathrm{~min}$, substrate $(\boldsymbol{S})$-1a underwent complete conversion giving a 2:1 mixture of diastereomeric products (Table I, entry 3 ). Extending the reaction period to $4 \mathrm{~h}$ did not alter the diastereomeric ratio $(d r)$ beyond 2:1 (Table I, entry 4). Furthermore, substrate $(S)$ $\mathbf{1 b}$, over a $10 \mathrm{~min}$ reaction time, underwent complete conversion giving a $d r$ of 8:1 and $68 \%$ isolated yield (Table I, entry 8 ). $\mathrm{N}$ bromosuccinimide (NBS) /dichloromethane $/ \mathrm{rt}$ reaction condition required $3 \mathrm{~h}$ for complete conversion and gave a 2:1 mixture of diastereomers (Table I, entry 1). It was also observed with $\mathrm{N}$-bromosuccinimide (NBS) that there was a $30 \mathrm{~min}$ induction period (Table I, entry 2). Both $\mathrm{I}_{2}$ and $\mathrm{PhSeBr}$ failed to effect cyclization (Table 1, entries 6 and 7$)$. Substrate $(\boldsymbol{S})$-1c gave a similar result to $(\boldsymbol{S})-1 \mathrm{a}$ with $\mathrm{Br}_{2} /$ dichloromethane $/-78^{\mathrm{O}} \mathrm{C}$. Substrates $(\boldsymbol{R})-\mathbf{2 a}, \mathbf{2 b}$ were then subjected to the best conditions achieved and comparable 
Table I. Cyclisation of $\delta$-hydroxy alkene moiety in $(S)$-1a,1b,1c and $(R)$-2a,2b

\begin{tabular}{|c|c|c|c|c|c|}
\hline Entry & Substrate & Conditions & Conver. $(\%)^{\mathrm{b}}$ & $d r^{\mathrm{c}}$ & Yield (\%) ${ }^{\mathrm{d}}$ \\
\hline 1 & $(S)-1 \mathrm{a}$ & $\mathrm{NBS} / \mathrm{DCM} / \mathrm{rt} / 3 \mathrm{~h}$ & 100 & $2: 1$ & 50 \\
\hline 2 & $(S)-1 \mathrm{a}$ & $\mathrm{NBS} / \mathrm{DCM} /-78^{\circ} \mathrm{C} / \mathrm{rt} / 30 \mathrm{~min}$ & 0 & - & - \\
\hline 3 & $(S)-1 \mathrm{a}$ & $\mathrm{Br}_{2} / \mathrm{DCM} /-78^{\circ} \mathrm{C} / 10 \mathrm{~min}$ & 100 & $2: 1$ & - \\
\hline 4 & $(S)-1 \mathrm{a}$ & $\mathrm{Br}_{2} / \mathrm{DCM} /-78{ }^{\circ} \mathrm{C}$ to $\mathrm{rt} / 4 \mathrm{~h}$ & 100 & $2: 1$ & - \\
\hline 5 & $(S)-1 \mathrm{a}$ & $\mathrm{Br}_{2} / \mathrm{DCM} /-78^{\circ} \mathrm{C} / 5 \mathrm{~min} / \mathrm{Na}_{2} \mathrm{CO}_{3}$ & 60 & $100: 0$ & 32 \\
\hline 6 & $(S)-1 \mathrm{a}$ & $\mathrm{I}_{2} / \mathrm{Py} / \mathrm{MeCN} / \mathrm{rt} / 20 \mathrm{~h}$ & - & - & - \\
\hline 7 & $(S)-1 \mathrm{a}$ & $\mathrm{PhSeBr} / \mathrm{MeCN} / \mathrm{rt} / 2 \mathrm{~h} / \mathrm{K}_{2} \mathrm{CO}_{3}$ & - & - & - \\
\hline 8 & $(S)-1 \mathrm{~b}$ & $\mathrm{Br}_{2} / \mathrm{DCM} /-78^{\circ} \mathrm{C} / 10 \mathrm{~min} /$ & 100 & $8: 1$ & 68 \\
\hline 9 & $(S)-1 \mathrm{~b}$ & $\mathrm{Na}_{2} \mathrm{CO}_{3}$ & 80 & $100: 0$ & 50 \\
\hline 10 & $(S)-1 \mathrm{c}$ & $\mathrm{Br}_{2} / \mathrm{DCM} /-78^{\circ} \mathrm{C} / 5 \mathrm{~min} / \mathrm{Na}_{2} \mathrm{CO}_{3}$ & 60 & $100: 0$ & 30 \\
\hline 11 & $(R)-2 \mathrm{a}$ & $\mathrm{Br}_{2} / \mathrm{DCM} /-78^{\circ} \mathrm{C} / 5 \mathrm{~min} / \mathrm{Na}_{2} \mathrm{CO}_{3}$ & 60 & $100: 0$ & 30 \\
\hline 12 & $(R)-2 \mathrm{~b}$ & $\begin{array}{l}\mathrm{Br}_{2} / \mathrm{DCM} /-78^{\circ} \mathrm{C} / 5 \mathrm{~min} / \mathrm{Na}_{2} \mathrm{CO}_{3} \\
\mathrm{Br}_{2} / \mathrm{DCM} /-78^{\circ} \mathrm{C} / 5 \mathrm{~min} / \mathrm{Na}_{2} \mathrm{CO}_{3}\end{array}$ & 80 & $100: 0$ & 52 \\
\hline
\end{tabular}

${ }^{a}$ All reactions employed $\mathbf{1 a}, \mathbf{1 b}, \mathbf{1 c}$ or $\mathbf{2 a}, \mathbf{2 b}(0.50 \mathrm{mmol})$ and $\mathrm{Br}_{2}(1.0 \mathrm{~mol}$ eq.) $(10 \% \mathrm{w} / \mathrm{v}$ solution in DCM) under nitrogen. ${ }^{b}$ Conversion by NMR. ${ }^{c}$ Ratio was determined from the proton NMR of the crude reaction mixture. ${ }^{\mathrm{d}}$ Isolated combined yield. DCM means dichloromethane and NBS means $N$ bromosuccinimide.

yields and diastereoselectivities were chiral centre in 3a, 3b, $\mathbf{c}$ was established as obtained (Table I, entries 11 and 12). $\quad(R)$. In the case of 3a, there was a $6.2 \%$ The relative stereochemistry of morpholine derivatives 3a, 3b, 3c was assigned from the experimental data of nuclear Overhauser effect (Fig. 1). Based on the known absolute configuration of starting materials $(S)-1 a-1 c$, the absolute configuration of the new $C-2$ enhancement of one of the $\mathrm{CH}_{2} \mathrm{Br}(\delta 3.47)$ proton when the axial proton at $\mathrm{C}(6)(\delta 3.2)$ was irradiated. This confirms that the $\mathrm{CH}_{2} \mathrm{Br}$ group at $C(2)$ is in the axial position and the configuration of $C(2)$ chiral centre is $(R)$. The observed $3.1 \%$ enhancement of the proton at $\mathrm{C}(5)(\delta 2.78-2.82, \mathrm{~m})$ when the

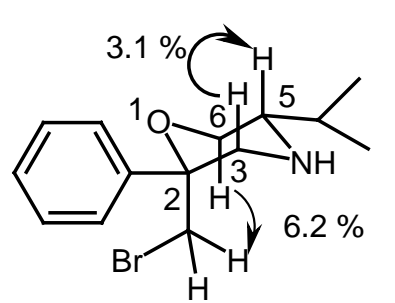

$(2 R, 5 S)-3 a$

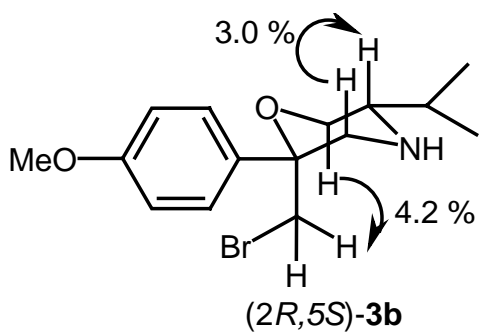

Fig. 1. n.O.e enhancements of (3a-c)

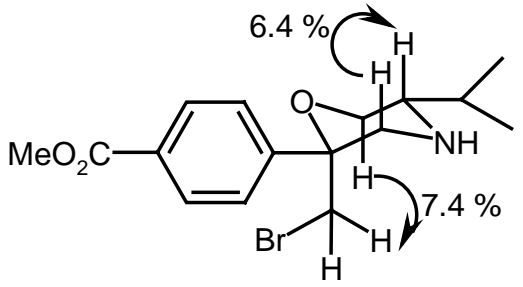

(2R,5S)-3c 
Table II. Diastereoselective synthesis of chiral morpholines (3a-c) and (4a, b) ${ }^{a}$

Entry Substrate

${ }^{a}$ All reactions employed $\mathbf{1 a}, \mathbf{1 b}, \mathbf{1 c}$ or $\mathbf{2 a}, \mathbf{2 b}(0.50 \mathrm{mmol})$ and $\mathrm{Br}_{2}(1.0 \mathrm{~mol}$ eq. $)(10 \% \mathrm{w} / \mathrm{v}$ solution in DCM) under nitrogen at $-78{ }^{\circ} \mathrm{C}$ for 5 min and afforded a single diastereomer. ${ }^{\mathrm{b}}$ Isolated yield.

axial proton at $\mathrm{C}(3)(\delta$ 4.5) was irradiated confirms that $\mathrm{C}(5)$ proton is axial and the isopropyl group at $\mathrm{C}(5)$ is equatorial. Nuclear Overhauser effect (n.O.e) experiments showed similar enhancements for 3b, 3c (Fig.1). Nuclear Overhauser effect experiments on compounds $\mathbf{4 a} \mathbf{a} \mathbf{4 b}$ were not conclusive. The stereochemistry of $\mathbf{4 b}$ (as the hydrobromide salt) was determined by X-ray crystallography as $(2 S, 5 R)$ (Fig. 2). The stereochemistry of $\mathbf{4 a}$ was assigned by an analogy with $\mathbf{4 b}$.

Presumably the reaction proceeds through the formation of bromonium ion followed by the intramolecular nucleophilic attack by $\mathrm{OH}$ to give the product. For substrates $(\boldsymbol{S})$ - 1a, 
1b,1c two chair-like transition states $5 \mathbf{a}$ and 5b (Scheme 2) are possible and it seems likely that the low energy transition state is 5a as both the sterically demanding phenyl and isopropyl group are in equatorial positions whereas in $\mathbf{5 b}$ the phenyl group is in the axial position, and thus energetically less favourable. For substrates $(\boldsymbol{R})-\mathbf{2 a}, \mathbf{2 b}$ two analogous chair-like transition states $\mathbf{6 a}$ and 2b (Scheme 3) are possible and the transition state 6a is energetically favoured as both the bulky phenyl groups are equatorial whereas in $6 \mathbf{b}$ one of the phenyl groups is axial and thus energetically less favourable.

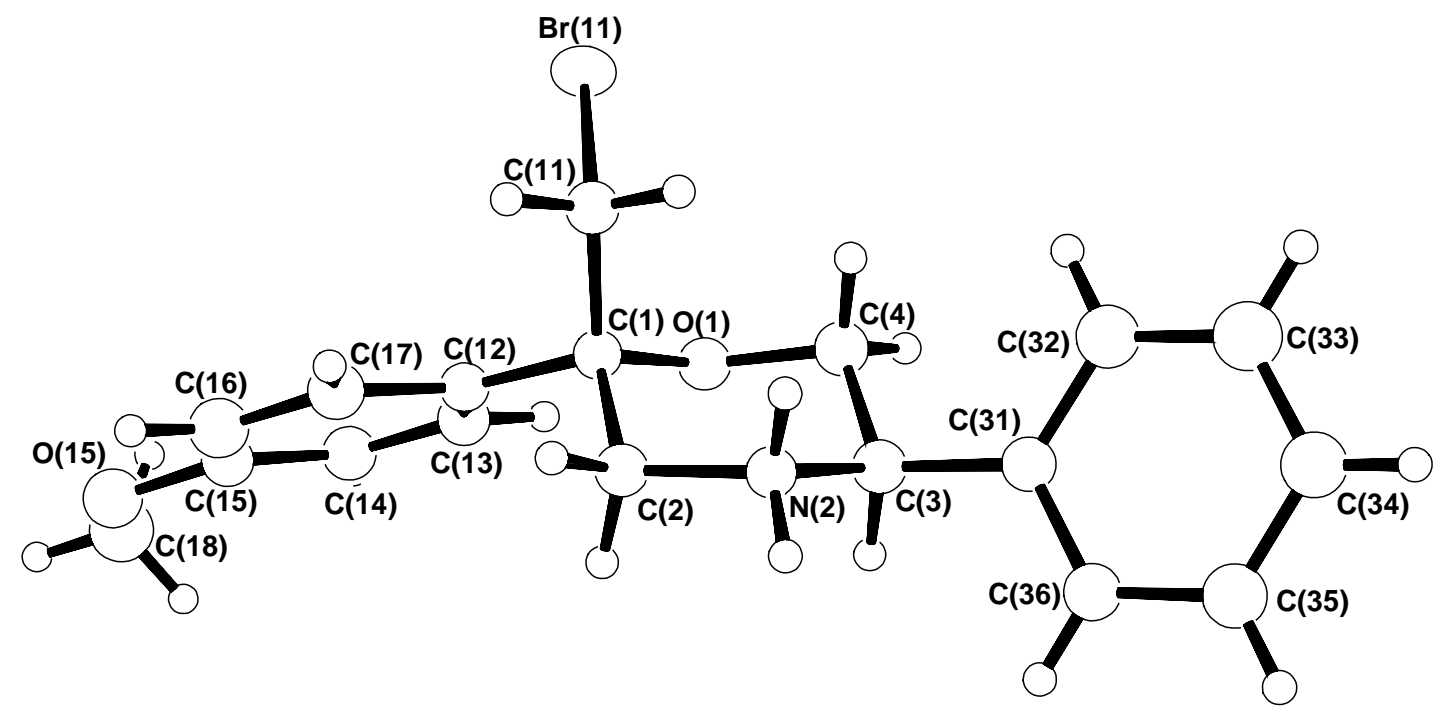

$\operatorname{Br}(\mathbf{1})$

Fig.2. X-ray crystal structure of $4 b$

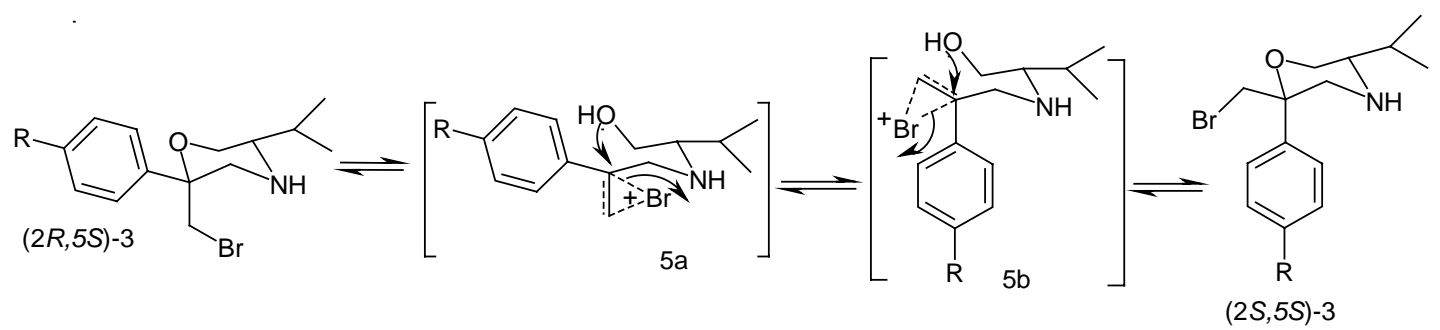

Scheme 2 
This theory predicts the preferred formation of $(2 R, 5 S)-\mathbf{3 a}, \mathbf{3 b}, \mathbf{3} \mathbf{c}$ and $(2 S, 5 R)-\mathbf{4 a}, \mathbf{4 b}$ over $(2 S, 5 S)-\mathbf{3 a}, \mathbf{3 b}, \mathbf{3 c}$ and $(2 R, 5 R)-\mathbf{4 a}, \mathbf{4 b}$ respectively over a short reaction time (5 min) in a kinetically controlled process. However, a reaction time of 10 min gives rise to an inseparable 2:1 mixture of diastereomers in almost all cases except for $(S)-1 b$ and $(\boldsymbol{R})$-2b which gave 8:1 mixtures of diastereomers. The electron donating noteworthy that if the reaction is quenched after $5 \mathrm{~min}$ it gives $60 \%$ conversion and 30 $32 \%$ isolated yield of single diastereomer, whilst a 2:1 mixture of two diastereomers were obtained if the reaction is allowed to go to complete conversion. However, electron donating substituent $(\mathrm{OMe})$ on the para position of the C-2 aryl moiety (substrates $(S)-1 \mathbf{b}$ and $(\boldsymbol{R})-\mathbf{2 b})$ accelerates the reaction to give $80 \%$ conversion and $50 \%$ isolated

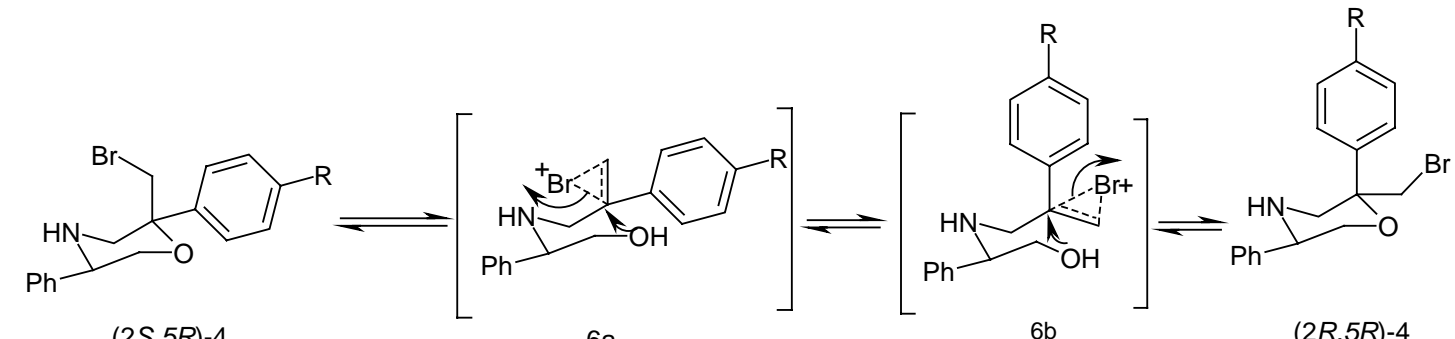

$(2 S, 5 R)-4$

$6 a$

Scheme 3

group of the styryl moiety can stabilize the bromonium ion and leads to a faster reaction affording better diastereoselectivities. This theory requires that a long reaction time and increased temperature ( $\mathrm{rt}, 4 \mathrm{~h})$ results in formation of the thermodynamic mixture.

\section{Conclusion}

Optically pure $N$-allyl- $\alpha$-amino alcohols $1 \mathrm{a}-\mathrm{c}$ and $(\boldsymbol{R})$-2a, $(\boldsymbol{R})$-2b were subjected to electrophile induced cyclization using bromine to give chiral morpholines $(2 R, 5 S)$ 3a-c and $(2 S, 5 R)-3 \mathbf{a}, \mathbf{3 b}$ respectively. It is yield of single diastereomer after $5 \mathrm{~min}$ and an 8:1 mixture of diastereomers on complete conversion after $10 \mathrm{~min}$.

\section{Acknowledgement}

We thank the Department of Applied Chemistry and Chemical Technology of Dhaka University for support.

\section{References}

Baldwin, S.W. Mclver, J. M. (1987) Stereoselective Synthesis of $( \pm)$ Methyl Nonacetate. J. Org. Chem. 52(2): 320-322. 
Bennet, F. Bedford, S.B. Bell, K.E. Fenton, G. Knight, D.W. Shaw, D. (1992) IodineInduced Cyclizations of (E)- and (Z)-SHydroxy-5-Alkenoates: Stereoselective Approaches to Trisubstituted Tetrahydrofurans. Tetrahedron Lett. 33(43): 65076510.

Bettler, B. Kaupmann, K. Bowery, N.G. (1998) $\mathrm{GABA}_{\mathrm{B}}$ receptors: drugs meet clones. Curr. Opin. Neurobiol. 8 : 345-350.

Blythin, D.J. Kuo, S.-C. Shue, H. -J. McPhail, A.T. (1996) Substituted Morpholine-2SAcetic Acid Derivatives: SCH 50911 and Related Compounds as Novel $\mathrm{GABA}_{\mathrm{B}}$ Antagonists. Bioorg. Med. Chem. Lett. 6(13) : 1529-1534.

Bowery, N.G. Enna, S.J. (2000) Gammaaminobutyric acid (B) receptors: first of the functional metabotropic heterodimers. $J$. Pharmacol. Exp. Ther. 292(1) : 2-7.

Bowery, N.G. Hill, D.R. Hudson, A.L. (1983) Characterisation of $\mathrm{GABA}_{\mathrm{B}}$ receptor binding sites on rat whole brain synaptic membranes. Br. J. Pharmacol. 78(2) : 191206.

Bowery, N.G. Hill, D.R. Hudson, A.L. Doble, A. (1980) (-) Baclofen decreases neurotransmitter release in a mamalian CNS by an action at a novel GABA receptor. Nature. 283 : 92-94.
Carai, M.A.M. Brunetti, G. Lobina, C. Serra, S. Vacca, G. Minardi, G. Colombo, G. Gessa, G.L. (2002) Proconvulsive effect of the $\mathrm{GABA}_{\mathrm{B}}$ receptor antagonist, $\mathrm{SCH} 50911$, in rats undergoing ethanol withdrawal syndrome. Eur. J. Pharmacol. 445 (3): 195199.

Colombo, G. Melis, S. Brunetti, G. Serra, S. Vacca, G. Carai, M.A.M. Gessa, G.L. (2001) $\mathrm{GABA}_{\mathrm{B}}$ receptor inhibition causes locomotor stimulation in mice. Eur. $J$. Pharmacol. 433(1) : 101-104.

Corey, P. F. (1987) Asymmetric Bromolactonization Reaction: Synthesis of Optically Active 2-Hydroxy-Methylalkanoic Acid from 2Methylenealkanoic Acid. Tetrahedron Lett. 28(25) : 2801-2804.

Couve, A. Moss, S.J. Pangalos, M.N. (2000) $\mathrm{GABA}_{\mathrm{B}}$ receptors: a new paradigm in $\mathrm{G}$ protein signaling. Mol. Cell. Neurosci. 16 : 296-312.

Ezquerra, J. He, W. Paquette, L.A. (1990) Enantiospecific Synthesis of the Tricyclic Nucleus of Acetoxycrenulide by Claisen Ring Expansion. Tetrahedron Lett. 31(48) : 6979-6982.

Gai, X. Grigg, R. Collard, S. Muir, J.E. (2001) Palladium catalysed 3-component cascade synthesis of bis(2-arylallyl)tertiary amines from aryl iodides, allene and primary 
amines. J. Chem. Soc., Chem. Commun. 1712-1713.

Hill, D.R. Bowery, N.G. (1981) ${ }^{3}$ H-Baclofen and ${ }^{3} \mathrm{H}-\mathrm{GABA}$ bind to bicuculline-insensitive $\mathrm{GABA}_{\mathrm{B}}$ sites in rat brain. Nature. 290 : 149-152.

Jung, M.E. D'Amico, D.C. Lew, W. (1993) Efficient Total Synthesis of the Cytotoxic Halogenated Monoterpene Aplysiapyranoid A. Tetrahedron Lett. 34 (6): 923-926.

Jung, M.E. Lew, W. (1991) Efficient Total Synthesis of the Cytotoxic Halogenated Monoterpene Aplysiapyranoid D. J. Org. Chem. 56(4): 1347-1349.

Kelley, J.L. Musso, D.L. Boswell, G.E. Soroko, F.E. Cooper, B.R. (1996) (2S,3S,5R)-2(3,5-Difluorophenyl)-3,5-dimethyl-2morpholinol: A Novel Antidepressant Agent and Selective Inhibitor of Norepinephrine Uptake. J. Med. Chem. 39 (2) : 347-349.

Kerr, D.I. Ong, J. (1995) GABA $_{\mathrm{B}}$ receptors. Pharmacol. Ther. 67(2) : 187-246.

Largeron, M. Neudorffer, A. Vuilhorgne, M. Blattes, E. Fleury, M. (2002) -B. Regiospecific Inverse-Electron-Demand Diels-Alder Reaction of Simultaneously Electrogenerated Diene and Dienophile: An Expeditious Route to Polyfunctionalized
1,4-Benzoxazine Derivatives. Angew. Chem. Int. Ed. 41 : 824-827.

Miura, K. Okajima, S. Hondo, T. Nakagawa, T. Takahashi, T. Hosomi, A. (2000) AcidCatalyzed Cyclization of Vinylsilanes Bearing a Hydroxy Group: A New Method for Stereoselective Synthesis of Disubstituted Tetrahydrofurans. J. Am. Chem. Soc. 122(46) : 11348-11357.

Mondadori, C. Preiswerk, G. Jaekel, J. (1992) Treatment with a $\mathrm{GABA}_{\mathrm{B}}$ receptor blocker improves the cognitive performance of mice, rats and rhesus monkeys. Pharmacol. Commun. 2 : 93-97.

Nicolaou, K.C. Magolda, R.L. Sipi, W.J. Bernette, W.E. Lysenko, Z. Jullie, M.M. (1980) Phenylselenoetherification. A Highly Efficient Cyclization Process for the Synthesis of O- and S-Heterocycles. J. Am. Chem. Soc. 102(11) : 3784-3793.

Ong, J. Marino, V. Parker, D.A.S. Kerr, D.I.B. Blythin, D.J. (1999) Antagonism of $\mathrm{GABA}_{\mathrm{B}}$ receptors by morpholino-2-acetic acid derivatives Sch 54679 and Sch 51324 in rat brain. Eur. J. Pharmacol. 369(1) : 33-37.

Reitz, A.B. Nortey, S.O. Maryanoff, B.E. Liotta, D. Monahan, I.R. (1987) Stereoselectivity of Electrophile-Promoted Cyclizations of $\gamma$ Hydroxyalkenes. An Investigation of Carbohydrate- Derived and Model 
Substrates. J. Org. Chem. 52(19) : 4191- Wood, M.D. Murkitt, K.L. Rice, S.Q. Testa, T. 4202 . Punia, P.K. Stammers, M. Jenkins, O. Elshourbagy, N.A. Shabon, U. Taylor, S.J.

Saksena, A. K. Girijavallabhan, V. M. Wang, H. C. Liu, Y. -T. Pike, R. E. Ganguly, A. K. (1996) Concise Asymmetric Routes to 2,2,4-Trisubstituted tetrahydrofurans via Chiral Titaniumimide Enolates: Key Intermediates Towards Synthesis of Highly Active Azole Antifungals SCH 51048 and SCH 56592. Tetrahedron Lett. 37(32) : 5657-5660.

Snead, O.C. (1992) Evidence for $\mathrm{GABA}_{\mathrm{B}}$ mediated mechanisms in experimental generalized absence seizures. Eur. J. Pharmacol. 213(3) : 343-349. Gager, T.L. Minton, J. Hirst, W.D. Price, G.W. Pangalos. M. (2000) The human $\mathrm{GABA}_{\mathrm{B} 1 \mathrm{~b}}$ and $\mathrm{GABA}_{\mathrm{B} 2}$ heterodimeric recombinant receptor shows low sensitivity to phaclofen and saclofen. $B r . J$. Pharmacol. 131(6) : 1050-1054.

Received: August 28, 2006;

Accepted : April 19, 2007 